\title{
ОЦІНКА ТА АНАЛІЗ ОСНОВНИХ КОНСТРУКТИВНИХ СХЕМ КОНУСНИХ ДРОБАРОК
}

\author{
Іван Назаренко, Євген Міщук, Віталій Кучинський \\ Київський національний університет будівництва і архітектури, \\ Повітрофрлотський пр-m, 31, 03680,Київ, Україна, e-mail: i_nazar@i.ua, jmishchuk@gmail.com
}

\section{ASSESSMENT AND ANALYSIS OF BASIC DESIGN THE CONE CRUSHERS}

\author{
Ivan Nazarenko, Eugen Mishchuk, Vitaly Kuchinsky \\ Kyiv National University of Construction and Architecture, \\ 31, Povitroflotsky Ave., 03680,Kyiv, Ukraine, e-mail: i_nazar@i.ua, jmishchuk@gmail.com
}

\begin{abstract}
АНОТАЦІЯ. В статmі представлені оцінка та аналіз існуючих конструкцій конусних дробарок з ексцентриковим та інерційним приводами. Проведена їх критеріальна оцінка та побудовані гістограми, на основі яких зроблені висновки відносно найбільш перспективних моделей конусних дробарок з метою їх удосконалення. Наведено результати теоретичних досліджень робочого процесу конусних дробарок у вигляді графріка витрат енергії в залежності від степеня дроблення при різних частотах обертання рухомого конуса та залежність вартості дроблення від крупності готового продукту.

Ключові слова: конусна дробарка,ексцентрик, критеріальна оцінка, вібрація.
\end{abstract}

АННОТАЦИЯ. В статье представлены оценка и анализ существующих конструкций конусных дробилок с эксцентриковым и инерционным приводами. Проведена их критериальная оценка и построены гистограммы, на основе которых сделаны выводы относительно наиболее перспективных моделей конусных дробилок с целью их усовершенствования. Приведены результаты теоретических исследований рабочего процесса конусных дробилок в виде графрика затрат энергии в зависимости от степени дробления при различных частотах вращения подвижного конуса и зависимость стоимости дробления от крупности готового продукта.

Ключевые слова: конусная дробилка, эксцентрик, критериальная оценка, вибрация.

ABSTRACT. Purpose. Summary of the main design features and installation of energy efficient design cone crusher. Methodology. The results of theoretical studies based on assessment and analysis of design parameters cone crushers. Finding. On the basis evaluation of criteria, built histograms that display the most perspective designs cone crushers. The results of theoretical research of working process cone crushers as a graph the effects of changes energy consumption depending on the degree of fragmentation at different speeds movable cone and dependence cost of crushing on the size of the finished product. Research limitations/implications. This research are forms the basis for further design of energy efficient cone crusher. Originality/value. The research results can be used to create cone crushers.

Key words: cone crusher, eccentric, criteria of estimation, vibration.

\section{ВСТУП}

Підвищення вимог до виробництва будівельних матеріалів та зменшення родовищ корисних копалин спонукає до пошуку енергоефективних конструкцій дробильних машин. При роботі дробарок в складі технологічних схем в кар'єрах або на будівельних майданчиках вихід з ладу даних машин $є$ недопустимим так як простої підвищують собівартість продукції. Не меншу увагу слід приділяти зниженню витрат на експлуатацію та підвищенню надійності елементів конструкції дробар- ки. Тобто, задача зниження енергоємності процесу дроблення та підвищення робочого ресурсу дробильної техніки $\epsilon$ актуальною.

В джерелах [1...4] наведені дослідження конструкцій конусних дробарок. В цих роботах розглядаються в основному конструкції конусних дробарок вітчизняних виробників. Крім того, деякі конструктивні особливості конусних дробарок не розглядались.

Основна мета роботи полягає в узагальненні основних конструктивних особливостей та встановлення енергоефективної конструкції конусної дробарки. 


\section{ВИКЛАД ОСНОВНОГО МАТЕРІАЛУ}

Конусні дробарки використовують на всіх стадіях дроблення при переробці різних за фізичними та геометричними параметрами руд і матеріалів. Виключенням $€$ матеріали i руди, які мають плитнякову структуру або містять глинисті фракції при підвищеній вологості. В першому випадку може відбуватись перевантаження привідного двигуна або збільшення крупності вихідного матеріалу, в другому відбувається часте спрацьовування амортизаційної системи і забивання камери дроблення [5]. Руйнування матеріалу в конусних дробарках здійснюється шляхом стискання i стирання його між конусами, які розташовані один всередині іншого. Стандартні конусні дробарки середнього i дрібного дроблення мають степінь дроблення 4...6 i забезпечують лещадність на рівні $25 \ldots 35 \%,[5,10,11]$.

Найбільшими і основними виробниками конусних дробарок є компанії "Metso" (Фінляндія), “Telsmith"(США), “Sandvik" (Швеція), “Уралмашзавод” (Росія).

На рис. 1, а наведена загальна будова гіраційної конусної дробарки.

Дробарка складається із масивної станини 1, середньої 2 та верхньої 3 секцій. Внутрішні поверхні секцій облицьовані змінними плитами із марганцевистої сталі. Зверху до фланця секції 3 прикріплена

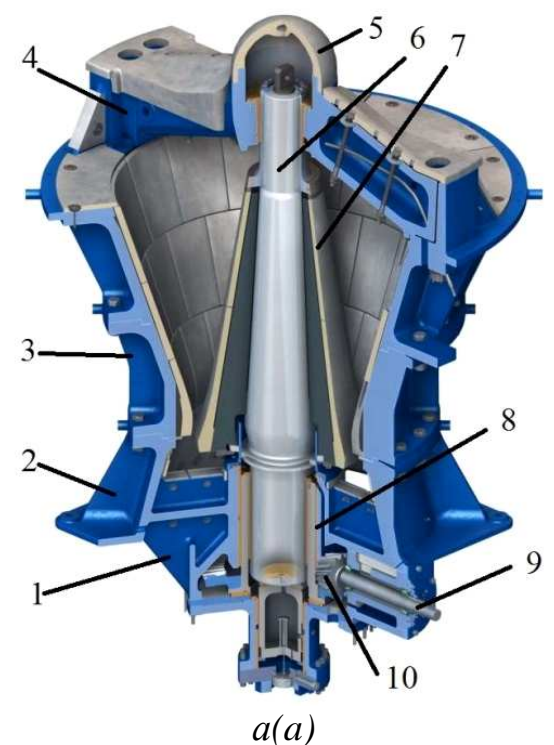

траверса 4, на якій розміщений вузол підвісу 5 вала рухомого конуса 6. Рухомий конус 7 запресований на вал 6 і також облицьований змінними плитами. В центрі станини 1 розташований ексцентриковий вузол 8 , що складається із ексцентрикового стакана 3 напресованим на нього конічним колесом. Вісь зовнішньої циліндричної поверхні ексцентрикового стакана співпадає 3 віссю дробарки, а вісь внутрішньої ексцентричної розточки стакана нахилена до осі дробарки і перетинається 3 нею в точці гірації. Ексцентрик отримує обертання від двигуна (не зображено на рис. 1, $a)$, клинопасової передачі (не зображено на рис. $1, a)$, привідного вала 9 і конічної передачі 10. Ексцентриковий вузол є найбільш навантаженим вузлом дробарки, який сприймає безпосередньо зусилля дроблення. В ранніх конструкціях конусних дробарок ексцентриковий стакан спирався на систему бронзових і сталевих шайб. 3 часом було прийнято рішення, яке дало змогу зменшити навантаження в даному вузлі за рахунок використання гідравлічних підп'ятників [1, 2, 7, 8].

Гіраційні дробарки характеризуються великим ходом рухомого конуса в нижній частині камери дроблення порівняно 3 ходом у верхній частині біля завантажувального отвору. Це сприяє підвищенню пропускної здатності та сипкому розподіленню матеріалу в камері дроблення. Дробар-

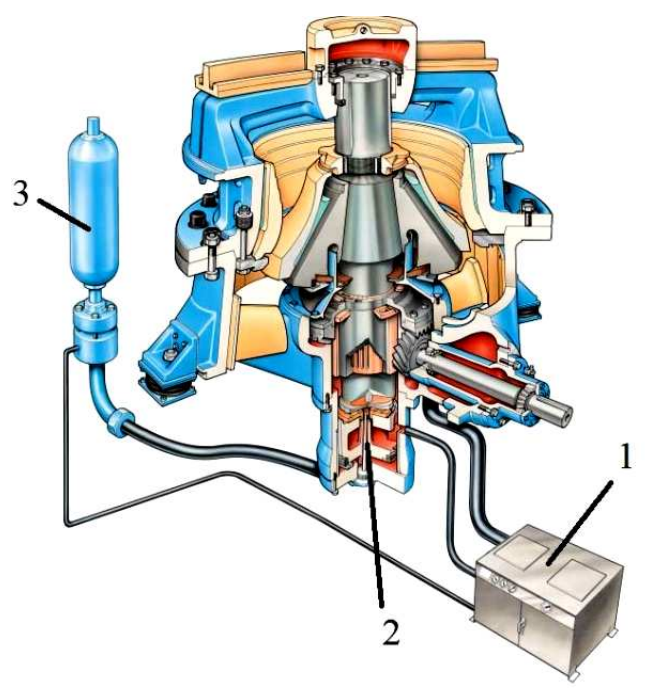

$\sigma(b)$

Рис. 1. Загальна будова конусної дробарки: гіраційної (a); гідравлічної (б)

Fig. 1. General design cone crusher: gyration $(a)$; hydraulic $(b)$ 
ки 3 верхнім розташуванням конуса $€$ надійними. Продуктивність гіраційних конусних дробарок досягає 200 т/год [1, 2, 4, 9].

Основними недоліками дробарок такої конструктивної схеми є трудність рівномірного розподілу дробленого матеріалу за периметром через відсутність завантажувальної тарілки; наявність траверси, яка частково перекриває завантажувальний простір [2, 4].

Наступним широко розповсюдженим типом конусних дробарок $є$ гідравлічні

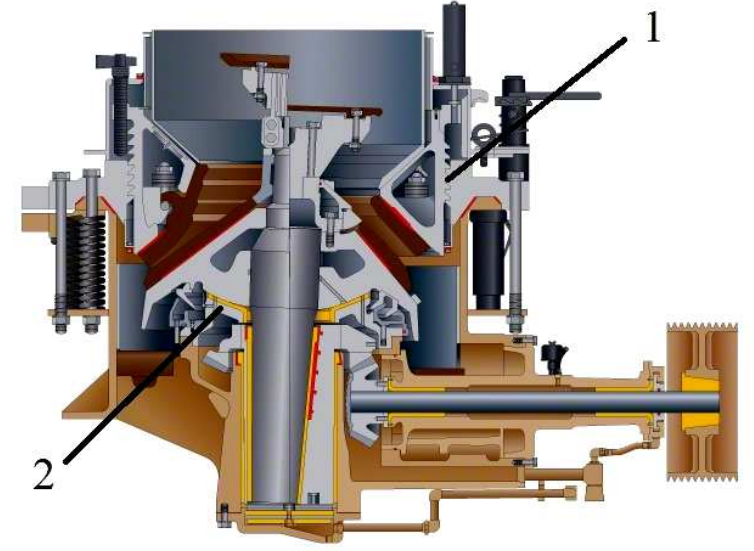

$a(a)$ розмір кусків. При переміщенні кусків один відносно одного забезпечується ефект стирання [5]. Продуктивність таких дробарок досягає 170 т/год при завантажувальному отворі 460 мм, а степінь дроблення знаходиться в межах $5[1,5,6]$.

Найбільш розповсюдженими на сьогодні типами конусних дробарок $є$ дробарки "Symons" (степінь дроблення 4) та "Telsmith" (степінь дроблення 6). Зазначені дробарки відрізняються між собою за рівнем надійності, вартості та експлуатацій-

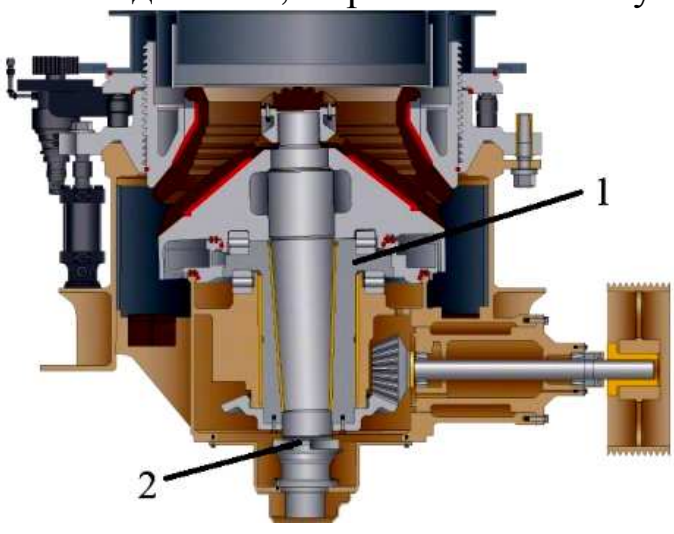

$\sigma(b)$

Рис. 2. Конусні дробарки: "Symons" (a); "Telsmith”(б)

Fig 2. Cone crushers: "Symons" (a); "Telsmith" $(b)$

конусні дробарки (рис. 1, б). Ці дробарки зручні в експлуатації, особливо при регулюванні розвантажувального отвору і пропуску недробимих тіл. Але вони $є$ найбільш дорогими. Регулювання розвантажувального отвору в гідравлічних конусних дробарках типу "Hydrocone" здійснюється гідроциліндром 2, який розташований під валом рухомого конуса. Під дією поршня внутрішній конус переміщується по вертикалі, компенсуючи знос броні конусів та корегуючи технологічні параметри. Гідравлічна схема такої дробарки містить гідронасос (розміщується в щитку 1) i гідробалон 3, який працює подібно амортизатору перешкоджаючи жорсткому удару і обмежуючи динамічні навантаження на ексцентричну втулку [4...7].

В дробарках типу “ Hydrocone " найкраще реалізується процес міжшарового примусового самодроблення. В цих машинах товщина шару матеріалу у фазі максимального зближення конусів перевищує них витрат [5, 6].

Основною відмінністю дробарок "Symons" $\epsilon$ те, що регулювання розміру між дробильними конусами здійснюється за допомогою різі $l$ (рис. 2. a), яка знаходиться на корпусі зовнішнього конуса.

Фірма "Telsmith" вдосконалила дробарку "Symons", замінивши сферичну опору ковзання внутрішнього конуса гіраційним диском кочення, який жорстко зв'язаний 3 привідною ексцентриковою втулкою 1 (рис.2, б). Вал рухомого конуса оснащений зубом, який знаходиться на його хвостовику. Зуб входить в зачеплення з відповідним зубом на дні корпусу дробарки, внаслідок чого унеможливлюється обертання конуса навколо своєї осі через затиснення вала привідним ексцентриком, а також нейтралізується зсув рухомого конуса на опорних підшипниках ковзання при підвищених обертах. Зазначені конструктивні рішення дозволяють підвищити число кругових 
коливань конуса та степінь дроблення $[5,6,9 \ldots 11]$.

Серед багатьох конструкцій конусних дробарок, які постійно вдосконалюються, можна виділити декілька їх типів. До них відноситься конусна дробарка "Girles", яка відрізнялась тим, що в ній відсутня конічна передача (рис. 3). Виготовляється в двох варіантах: 3 нижнім розташуванням клинопасової передачі та 3 вбудованим електродвигуном. Радіальною опорою електродвигуна служить фланець 2 , який кріпится до корпусу дробарки. Ще одною особливістю дробарки є застосування кінематичного шарніру 1 в ексцентриковому вузлі, який виключає перекоси в підшипниках ковзання ексцентрикового вузла.

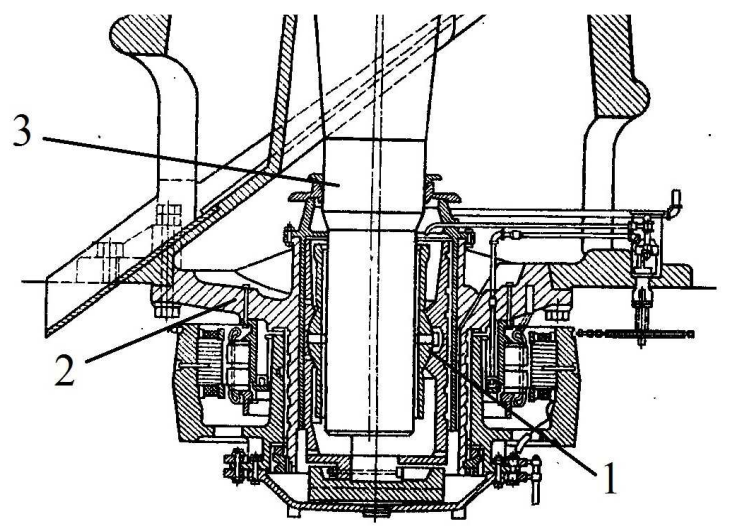

Рис. 3. Конусна дробарка "Girles"

Fig. 3. Cone crusher "Girles"

Виключення конічної передачі та значних махових мас, розміщених на ексцентрику, дозволило використовувати електродвигун на $40 \%$ меншої потужності, ніж у звичайних конусних дробарках крупного подрібнення [4].

Іншим цікавим рішенням $є$ конусна дробарка, запропонована К.А. Рундквістом. В дробарці переміщення рухомого конуса здійснюється за рахунок двох шатунів 1 (рис. 4), які передають рух на загальну втулку, що охоплює кінець вала рухомого конуса. Шатуни приводяться до руху двома вертикальними ексцентриковими валами 2, що кінематично зв'язані із загальним горизонтальним привідним валом 4. Інерційні сили шатунів і рухомого конуса врівноважуються дебалансами 3, які змонтовані на вертикальних валах. Недоліком дробарки є рухома опора циліндру в центральному стакані корпусу дробарки. Так, при виникненні радіальних зусиль дроблення можливе заклинювання рухомої опори $[4,5]$.

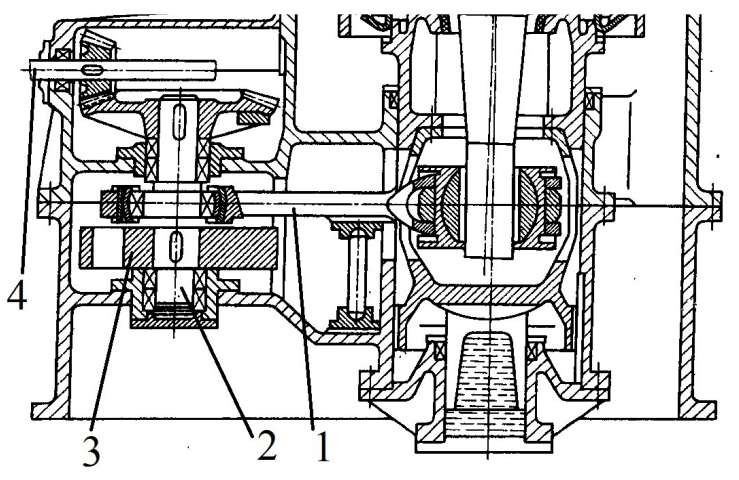

Рис. 4. Конусна дробарка з шатунним приводом

Fig. 4. Cone crusher with connecting rod drive

Інтерес становить дробарка фірми "Babbitless" (рис.5, a), в конструкції якої замість підшипників ковзання використовують підшипники кочення. Використання цих підшипників дозволяе прийняти відносно високу частоту коливань рухомого конуса, що, в свою чергу, сприяє використанню в дробарках крутого профілю дробильної камери. Недоліком цієї конструкції є підвищена висота дробарки внаслідок збільшення довжини вала рухомого кону$\mathrm{ca}$, що зроблено з метою зниження навантажень на ексцентриковий вузол. Таке конструктивне рішення опор ексцентрикового вала обмежує можливості створення дробарок великих типорозмірів [4, 5]. На сьогодні дробарки "Babbitless" виготовляє компанія "Теrex” (США) (рис.5, б). Ці дробарки забезпечують продуктивність до 350 т/год при розмірах розвантажувального отвору 32 мм та завантажувального отвору 220 мм [7, 8].

3 аналізу конструкцій ексцентрикових конусних дробарок випливає, що основними напрямками їх вдосконалення є підвищення надійності деталей та вузлів, полегшення монтажних і ремонтних робіт та підвищення технологічних можливостей за рахунок зміни конструкції окремих вузлів. Подальше покращення технологічних по- 
казників дробарок в зв'язку із жорсткістю кінематичних зв'язків між дробильними робочими органами $\epsilon$ утрудненим. Також $\epsilon$ проблеми iз селективним руйнуванням матеріалів та неможливістю переробки особливо міцних порід. Ці недоліки ексцентрикових конусних дробарок вдалось вирішити в конусній інерційній дробарці [9].

Основна відмінність конусної інерційної дробарки від дробарки "Symons" полягає в тому, що ексцентрик замінений привідним вібратором дебалансного типу.

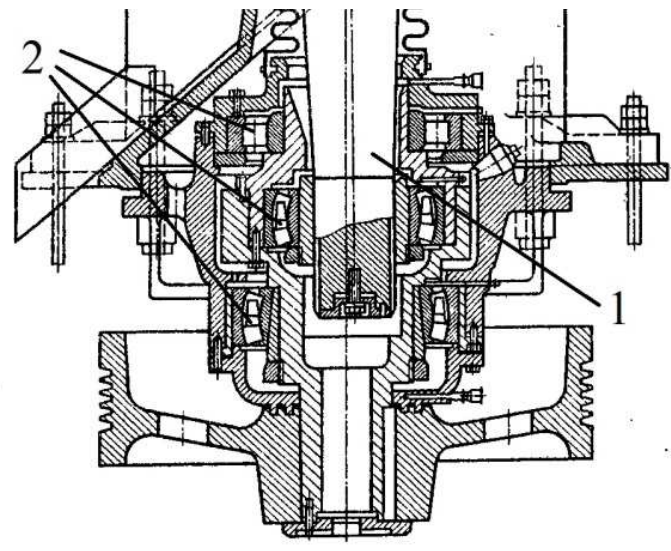

$a(a)$ них дробарках відсутне поняття розвантажувального отвору, яке прийняте для ексцентрикових дробарок. Під розвантажувальним отвором в конусних інерційних дробарках прийнято розмір діаметрального кільцевого зазору між конусами при зміщенні їх осей $[5,6]$. Інша особливість конусних інерційних дробарок це відмінність в характері дробильного зусилля. В ексцентриковій дробарці дробильне зусилля залежить від міцності породи і степені заповнення нею камери дроблення. В інер-

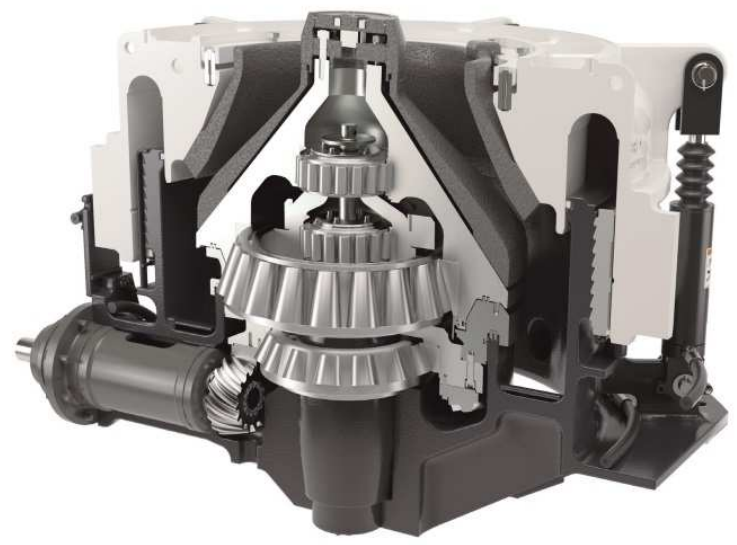

$\sigma(b)$

Рис. 5. Конусна дробарка фірми "Babbitless" (a); компанії “Terex” серії ТС (б)

Fig 5. Cone crusher firm "Babbitless" $(a)$; company "Terex" TC series $(b)$

Будова конусної інерційної дробарки наведена на рис. 6. Вона складається із зовнішнього конуса 1 та внутрішнього рухомого конуса 2. На валу дробильного конуса 3 змонтовано за допомогою підшипника 4 дебалансний вібратор 6 , який приводиться в обертання через гнучку трансмісію 5. При обертанні дебалансного вібратора створюється відцентрове зусилля, яке змушує дробильний конус обкочуватись по циліндричній поверхні зовнішнього конуса без зазору якщо в камері дроблення не має перероблюваного матеріалу або через шар матеріалу.

У вібраційній конусній дробарці степінь дроблення досягає 15...20. Питомі витрати енергії на одиницю утвореної поверхні в цих дробарках нижчі в 1,4...1,6 рази в порівнянні з ексцентриковими [5].

За рахунок відсутності жорстких кінематичних зв'язків між конусами в інерцій- ційних дробарках дробильна сила $є$ сумою відцентрової сили дебаланса i рухомого конуса при його русі. Це зусилля не залежить від властивостей перероблюваного матеріалу [9]. В дробарках 3 інерційним

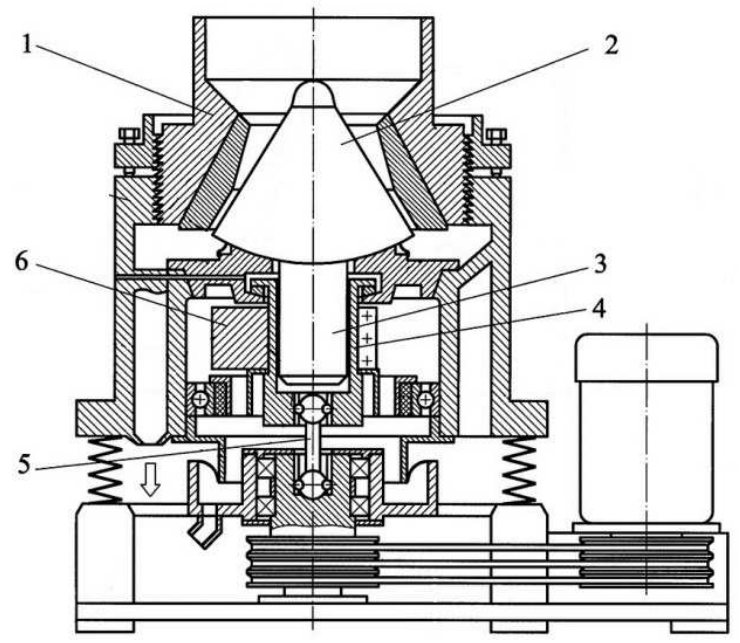

Рис. 6. Конусна інерційна дробарка

Рис. 6. The inertial cone crusher 
приводом можливе значне збільшення частоти кочення внутрішнього конуса, що також позитивно впливає на ефективність роботи даної конструкції $[5,6]$.

На основі аналізу конструктивних схем конусних дробарок були визначені їх основні технологічні характеристики (табл.).

Таблиця. Технічні характеристики конусних дробарок основних світових виробників

Table. Technical specifications of cone crushers of the major world producers

\begin{tabular}{|l|l|l|l|}
\hline $\begin{array}{l}\text { Модель } \\
\text { (виробник) }\end{array}$ & $\begin{array}{l}\text { Потуж- } \\
\text { ність } \\
\text { N, кВт }\end{array}$ & $\begin{array}{l}\text { Про- } \\
\text { дук- } \\
\text { тив- } \\
\text { ність } \\
\begin{array}{l}\text { П, } \\
\text { т/год }\end{array}\end{array}$ & $\begin{array}{l}\text { Маса } \\
\text { кг }\end{array}$ \\
\hline HР-300 (Metso) & 220 & 440 & 15,8 \\
\hline $\begin{array}{l}\text { TMC-3 } \\
\text { (TRIMAN) }\end{array}$ & 160 & 435 & 16 \\
\hline CH440 (Sandvik) & 220 & 395 & 14,3 \\
\hline MVP280 (Terex) & 200 & 305 & 16,556 \\
\hline $\begin{array}{l}\text { КСД-1750 } \\
\text { Гр-Д(HКМ3) }\end{array}$ & 160 & 512 & 51 \\
\hline $\begin{array}{l}\text { WКS } 160- \\
\text { В(ССRВ) }\end{array}$ & 160 & 349 & 26,5 \\
\hline $\begin{array}{l}\text { 44 SВХ } \\
\text { (Теlsmith) }\end{array}$ & 220 & 472 & 16,556 \\
\hline $\begin{array}{l}\text { КИД-1200 } \\
\text { (Механобр) }\end{array}$ & 200 & 180 & 30 \\
\hline
\end{tabular}

На основі аналізу техніко-економічних показників була визначена група критеріїв для оцінки ефективності конструкцій конусних дробарок. До таких критеріїв від- носяться: $\mathrm{k}_{1}=\frac{\Pi}{\mathrm{m}}-$ критерій оцінки впливу маси на продуктивність; $\mathrm{k}_{2}=\frac{\Pi}{\mathrm{P}}-$ критерій впливу витрат енергії на продуктивність; $\mathrm{k}_{3}=\frac{\mathrm{m}}{\mathrm{P}}$ - критерій впливу потужності на масу.

Для обгрунтування й вибору тієї чи іншої схеми конструкції машини були побудовані гістограми (рис. 7).

Найбільш раціональними за конструктивним виконанням $\epsilon$ ексцентрикові конусні дробарки компаній "Telsmith", "Sandvik", "Metso", "НКМЗ". Конусні інерційні дробарки мають нижчі значення показників в порівнянні з ексцентриковими. Це можна пояснити відносною новизною конструкції цих дробарок, які $є$ не в повній мірі дослідженими, та тим, що наведені показники не можуть в повній мірі описати переваги конструкції конусної дробарки з вібраційним приводом.

Загальним недоліком всіх типів дробарок $\epsilon$ низький степінь дроблення, що пояснюється двома факторами. Першим фактором $\epsilon$ обмежена амплітуда коливань конуса відносно осі обертання. Через це шар матеріалу низької міцності не може бути деформований на величину, більшу за встановлений зазор. Другим фактором $\epsilon$ обмежена частота коливань рухомого конуса. 3 підвищенням частотної дії на матеріал знижується крупність матеріалу, проте збільшується відцентрова сила рухомого конуса і, відповідно, степінь неврівноваженості дробарки. Встановлено, що ене-
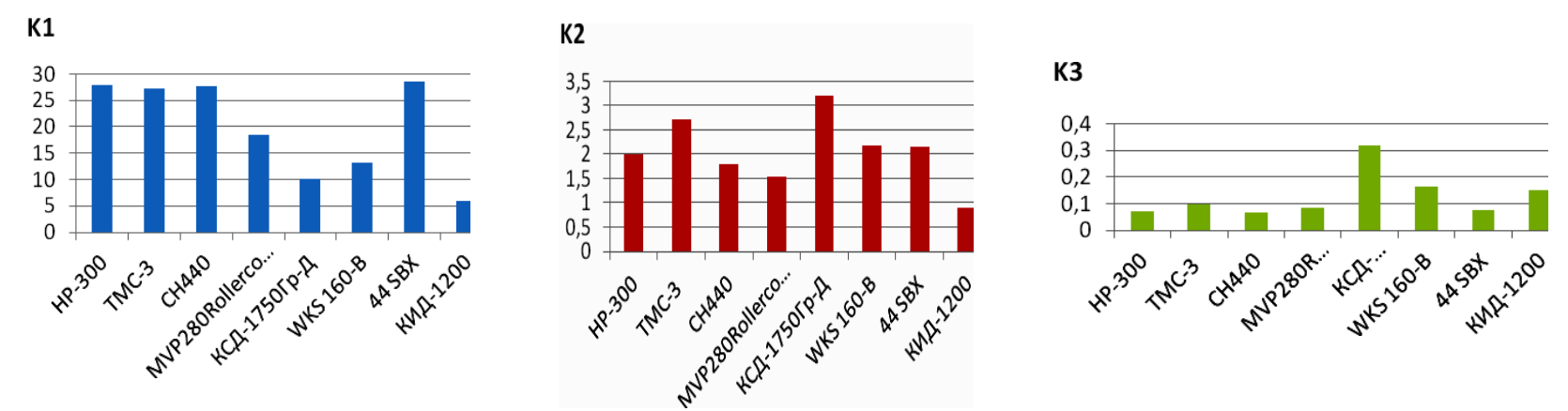

Рис. 7. Значення критеріїв K1, K2, K3 для різних типів дробарок

Fig. 7. The value criteria K1, K2, K2 for different types of crushers 


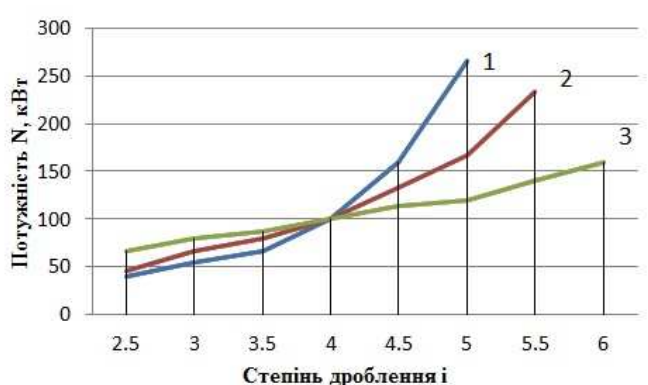

$a(a)$

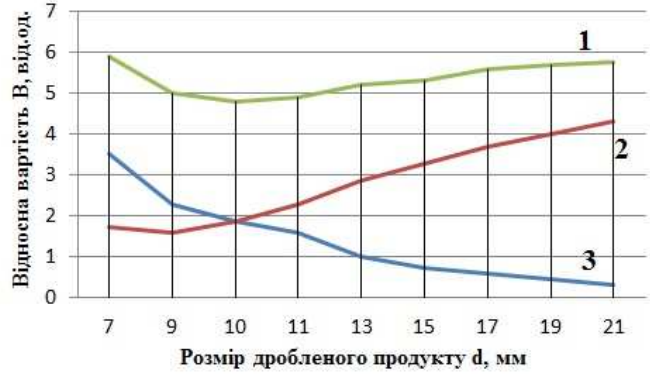

$\sigma(b)$

Рис. 8. Графіки залежності потужності від степеня дроблення при частотах: 1 - 224 об/хв.; 2 - 270 об/хв.; 3 - 338 об/хв. (a); відносної вартості В від розмір продукту d ( 1 - дроблення і помел в сумі; 2 - помел; 3 - дроблення) (б)

Fig. 8. Graph of dependence: power on the degree of fragmentation at frequencies:

$1-224 \mathrm{rpm} ; 2-270 \mathrm{rpm} ; 3-338 \mathrm{rpm}($ a) ; size d of crushed product of the relative value of B ( $1-$ crushing and grinding in the amount; 2 - grinding; 3 - crushing) (b)

ргоємність процесу дроблення зменшується $з$ підвищенням частоти коливань рухомого конуса. На рис. 8, а зображено графік зміни потужності в залежності від степеня дроблення при різних частотах.

В ексцентрикових дробарках при збільшенні швидкості коливань конуса виникає загроза руйнування фундаменту.

На холостому ходу відбувається зміщення рухомого конуса, частковий вихід вала із гнізда ексцентрик та наступне його затискання.

Сьогодні спостерігається тенденція часткової заміни млинів конусними дробарками. Проте, поки що не існує конусних ексцентрикових дробарок, здатних забезпечити надтонке дроблення. Так, традиційна схема обробки руди містить три стадії дроблення в ексцентрикових дробарках (ККД - конусна крупного дроблення, КСД - конусна середнього дроблення, КСД конусна середнього дроблення) та дві стадії помелу (стрижневий млин, шаровий млин). Таку схему з успіхом можна замінити, використовуючи вібраційну техніку, а саме дві стадії дроблення (ВЩД - вібраційна щокова дробарка, КІД - конусна інерційна дробарка) та одну стадію помелу з використанням шарового млина. Залежності вартості дроблення, помелу та загальної вартості підготовки руди від крупності дробленого продукту наведено на рис. 8,6 .

\section{ВИСНОВКИ}

До основних факторів, які обмежують застосування конусних дробарок, відносяться еліптичність і неконцентричність броні конусів; підвищені радіальні зазори в привідному ексцентриковому механізмі; чутливість до нерівномірності завантаження; обмежена частота коливань рухомого конуса.

Більшість підприємств 3 виготовлення будівельних матеріалів та обробки руди йде шляхом збільшення стадійності і введенням додаткових дробильних машин. Це призводить до підвищення вартості готового продукту та збільшенню експлуатаційних витрат.

При проектуванні ексцентрикових та вібраційних конусних дробарок використовуються емпіричні залежності, які не в повній мірі враховують вплив дробимого матеріалу на робочий процес.

Найбільш перспективними конструкціями конусних дробарок є вібраційні конусні дробарки та ексцентрикові конусні дробарки “Telsmith”.

\section{ЛІТЕРАТУРА}

1. Назаренко I.I. Машини для виробництва будівельних матеріалів: Підручник. - / I.I. Назаренко.// - К.: КНУБА, 1999. - 488 с.

2. Сапожников М.Я. Механическое оборудование предприятий строительных материа- 
лов, изделий и конструкций / М.Я. Сапожников. - М., «Высш. школа», 1971. - 382с.

3. Сівко В.Й. Механічне устаткування підприємств будівельних виробів. - К.:Вища шк.. 1994, $364 \mathrm{c}$.

4. Клушанцев Б.В. Дробилки. Конструкция, расчет, особености експлуатации / Б.В. Клушанцев, А.И. Косарев, Ю.А. Муйземнек. - М.: Машиностроение, 1990. - 320 с.

5. Блохин В.С. Основные параметры технологических машин. Машины для дезинтеграции твердых материалов: пособие. ч.I / В.С. Блохин, В.И. Большаков, Н.Г. Малич. Днепропетровск: ИМА-пресс, 2006. - 404c.

6. Вайсберг Л.А. Вибрационные дробилки. Основы расчета, проектирования и технологического применения / Л.А. Вайсберг, Л.П. Зарогатский, В.Я. Туркин. - СПб.: ИзД-во ВСЕГЕИ, 2004. - 306 с.

7. Cone Crusher. Brochure. B5-132:ENG Sandvik SRP AB 2014. - 20 p.

8. Конусные дробилки Nordberg серии НР. Брошюра № 2110-03-07-CSR/St.Petersburg 2007 Metso Minerals. - 12p.

9. Демченко C.E. Основные технологические показатели конусной инерционной дробилки. Методики расчёта / С.Е. Демченко // Строительные и дорожные машины. 2007. - №7. - C. 18-20.

10. Коровников А.Н. Современное оборудование НПК «Механобр-техника» для переработки рудных материалов / А.Н. Коровников // Обогащение руд. 2004. - № 6. - С. 3640.

11. Муйземнек Ю.А. Теория и практика рабочего процесса в конусных дробилках / Ю.А. Муйземнек // Изв. ВУЗов. Горный журнал. 2002. - №1. - С. 101-109.

\section{REFERENCES}

1. Nazarenko I.I., 1999. Mashini dlja virobnictva budivel'nih materialiv [Machines for the production of building materials]. Kyiv, KNUCA Publ., 488. - (in Ukrainian).

2. Sapozhnikov M.Ja., 1971. Mehanicheskoe oborudovanie predprijatij stroitel'nyh materialov, izdelij i konstrukcij [Mechanical equipment of enterprises of building materials, products and structures]. Moscow, Vyssh. Shkola Publ., 382. - (in Russian).

3. Sivko V.J., 1994. Mehanichne ustatkuvannja pidpriemstv budivel'nih virobiv [Mechanical equipment of enterprises of building materi- als]. Kyiv,Vishha shkola Publ., 364. - (in Ukrainian).

4. Klushancev B.V., Kosarev A.I., Mujzemnek Ju.A., 1990. Drobilki. Konstrukcija, raschet, osobenosti ekspluatacii [Crushers. Design, calculation, operation features]. Moscov, Mashinostroenie, 320. - (in Russian).

5. Blohin V.S., Bol'shakov V.I., Malich N.G., 2006. Osnovnye parametry tehnologicheskih mashin. Mashiny dlja dezintegracii tverdyh materialov: posobie. ch.I [The main parameters of production machines. Machines for the disintegration of solid materials: manual. Ch.I], Dnepropetrovsk, IMA-press Publ., 404. - (in Russian).

6. Vajsberg L.A., Zarogatskij L.P., Turkin V.Ja., 2004. Vibracionnye drobilki. Osnovy rascheta, proektirovanija i tehnologicheskogo primenenija [Vibrating mills. Bases for design, engineering and technological applications]. St. Peterb. VSEGEI Publ., 306. - (in Russian)

7. Cone Crusher, 2014. Brochure. B5-132:ENG Sandvik SRP AB 20. - (in Russian).

8. Cone crushers, 2007. Nordberg HP series. Brochure No 2110-03-07-CSR/St. Petersburg Metso Minerals, 12. - (in Russian)

9. Demchenko S.E., 2007. Main technologicalcal performance inertial cone crusher. Methods of calculation [Basic technological parameters of inertia cone crusher. Methods of calculation]. Building and road machines [Construction and road machines], No. 7, 1820.

10. Korovnikov A.N., 2004. Sovremennoe oborudo-vanie NPK «Mehanobr-tehnika» dlja pererabotki rudnyh materialov [Modern equipment NPK "Mekhanobr tekhnika" for the processing of ore materials]. Obogashhenie rud [Ore enrichment], No. 6. 36-40. - (in Russian)

11. Mujzemnek Ju.A., 2002. Teorija i praktika rabochego processa $\mathrm{v}$ konusnyh drobilkah [Theory and practice of the working process in cone crushers]. Izv. VUZov, Gornyj zhurnal, No. 1, 101-109. - (in Russian). 